International Journal of Mechanical Engineering and Technology (IJMET)

Volume 12, Issue 3, March 2021, pp. 9-19. Article ID: IJMET_12_03_002

Available online at https://iaeme.com/Home/issue/IJMET?Volume=12\&Issue=3

ISSN Print: 0976-6340 and ISSN Online: 0976-6359

DOI: https://doi.org/10.34218/IJMET.12.3.2021.002

(C) IAEME Publication

Scopus Indexed

\title{
REDUCTION OF EXHAUST EMISSIONS OF SEMI ADIABATIC DIESEL ENGINE WITH ALTERNATIVE FUELS
}

\author{
N. Janardhan and Dr M.V.S. Murali Krishna* \\ Mechanical Engineering Department, Chaitanya Bharathi Institute of Technology, \\ Gandipet, Hyderabad, India \\ *Corresponding Author
}

\begin{abstract}
Drawbacks associated with crude vegetable oils (high viscosity and low volatility) and alcohol (low energy content and cetane number) for use in compression ignition engine call for biodiesels. These biodiesels have numerous advantages compared to fossil fuels as they are renewable, biodegradable, provide energy security and foreign exchange savings besides addressing environmental concerns and socio-economic issues. However, these alternative fuels (vegetable oils and its biodiesels) are highly to moderate viscous and require hot combustion chamber, provided by semi adiabatic diesel engine. Investigations were carried out to determine exhaust emissions of a high grade semi adiabatic diesel engine consisted of air gap insulated piston, air gap insulated liner and ceramic coated cylinder head with different operating conditions [normal temperature and pre-heated temperature] of crude rice bran oil and its biodiesel with varied injector opening pressure. Exhaust emissions were determined at various values of brake mean effective pressure of the engine fuelled with crude rice bran oil and its biodiesel. Comparative studies on exhaust emissions were made with diesel working on similar conditions. Particulate emissions decreased, while $\mathrm{NO}_{x}$ levels increased with LHR engine with biodiesel operation. Exhaust emissions improved with increase of injector opening pressure and preheating of biodiesel.
\end{abstract}

Key words: Alternative fuels, biodiesel, injection pressure, preheating, exhaust emissions, vegetable oils.

Cite this Article: N. Janardhan and M.V.S. Murali Krishna, Reduction of Exhaust Emissions of Semi Adiabatic Diesel Engine with Alternative Fuels, International Journal of Mechanical Engineering and Technology (IJMET), 12(3), 2021, pp. 9-19. https://iaeme.com/Home/issue/IJMET?Volume=12\&Issue=3 


\section{INTRODUCTION}

In the context of depletion of fossil fuels, the search for alternative fuels has become pertinent. Vegetable oils and alcohols are promising substitutes for diesel fuels. They are renewable and can be easily produced. Rudolph Diesel, the inventor of the diesel engine that bears his name, experimented with fuels ranging from powdered coal to peanut oil [1]. Most of the alcohols produced in India is diverted to Petro-chemical industries, That too, they have low cetane number and energy content. Hence, vegetable oils can be used in diesel engine without major modifications of the engine hardware. Several researchers experimented the use of vegetable oils as fuel on diesel engine and reported that the performance was poor, citing the problems of high viscosity, low volatility and their polyunsaturated character. [2-7]. The drawbacks associated with crude vegetable oil for use in diesel engine of high viscosity and low volatility were reduced to some extent, if crude vegetable oils are chemical converted into biodiesel. Experiments were conducted with biodiesel in conventional engine. [8-11].They reported that marginal improvement of performance and reduction of particulate emissions and increase of nitrogen oxide levels with biodiesel operation in comparison with diesel operation on conventional engine.

Experiments were conducted on preheated vegetable oils [temperature at which viscosity of the vegetable oils were matched to that of diesel fuel]. [12-15]. They reported that preheated vegetable oils decreased pollution levels of particulate emissions and $\mathrm{NO}_{\mathrm{x}}$ emissions. By controlling the injector opening pressure and the injection rate, the spray cone angle is found to depend on injector opening pressure [16]. Few investigators reported that injector opening pressure has a significance effect on the performance and formation of pollutants inside the direct injection diesel engine combustion. [ 17-20]. They reported that particulate emissions decreased with increase of injector opening pressure. However drawbacks associated with biodiesel of high viscosity and low volatility which cause combustion problems, call for engine with hot combustion chamber with its significant characteristics of higher operating temperature, maximum heat release, and ability to handle the low calorific value fuel. The concept of the engine with LHR combustion chamber or semi adiabatic engine is reduce heat loss to the coolant, by providing thermal resistance in the path of heat flow to the coolant. Any saving in this part of the energy distribution would either increase the energy lost through exhaust gases or increase the power output. Considerable efforts are under way to reduce heat loss to the coolant by various researchers. However, the results are a little confusing as to whether the insulation would improve or deteriorate thermal efficiency. Three approaches that are being pursued to decrease heat rejection are (1) Coating (low grade LHR combustion chamber or LHR-1 engine) with low thermal conductivity materials on crown of the piston, inner portion of the liner and cylinder head, (2) air gap insulation (medium grade LHR combustion chamber or LHR-2 engine) where air gap is provided in the piston and other components with low-thermal conductivity materials like superni, cast iron and mild steel and (3).High grade LHR combustion chamber or LHR-3 engine is the combination of low grade and medium grade LHR combustion chambers. Experiments were conducted on conventional engine with high grade LHR combustion chamber, consisting of air gap ( $3 \mathrm{~mm}$ ) insulated piston with superni crown, fitted to the body of the piston by threading by keeping a gasket made of superni material, air gap insulated liner with superni insert and ceramic coated cylinder head (partially stabilized zirconium of thickness 500 microns coated on inside portion of cylinder head) with biodiesel with varied injector opening pressure and injection timing [21-23]. The optimum injection timing was observed to be $28^{\circ} \mathrm{bTDC}$ with high grade LHR combustion chamber with biodiesel operation. It was reported from their investigations, that thermal efficiency increased by $12-14 \%$, volumetric efficiency decreased by $5-7 \%$, particulate emissions decreased by $56-58 \% \mathrm{NO}_{\mathrm{x}}$ levels increased by $46-50 \%$, peak pressure increased by 
$30-32 \%$ and maximum rate of pressure increased by $8-10 \%$ with engine with LHR combustion chamber with biodiesel at optimum injection timing when compared with neat diesel operation at $28^{\circ}$ bTDC. Experiments were extended to crude vegetable oil operation on high grade LHR engine. [24-26]. The optimum injection timing was observed to be $29^{\circ}$ bTDC with high grade LHR combustion chamber with crude vegetable oil operation. It was reported from their investigations, that thermal efficiency increased by $8-10 \%$, volumetric efficiency decreased by 4-6\%, particulate emissions decreased by $25-30 \%, \mathrm{NO}_{\mathrm{x}}$ levels increased by $25-30 \%$, peak pressure increased by 15-20\% and maximum rate of pressure increased by 4-6\% with engine with LHR combustion chamber with crude vegetable oil at its optimum injection timing when compared with neat diesel operation at $28^{\circ}$ bTDC.

Little literature was available on comparative studies on exhaust emissions with crude rice bran oil and its biodiesel with high grade LHR engine or LHR-3 engine. Hence an attempt was made here to determine exhaust emissions with crude rice bran oil and its biodiesel with LHR3 engine consisting of air gap insulated piston, air gap insulated liner and ceramic coated cylinder head at different operating conditions with varied injector opening pressure and compared with $\mathrm{CE}$ with crude vegetable oil and its biodiesel.

\section{MATERIALS AND METHODS}

\subsection{Preparation of Biodiesel}

The chemical conversion of esterification reduced viscosity fourfold. Crude rice bran oil contains up to $70 \%$ (wt.) free fatty acids. The methyl ester was produced by chemically reacting the crude rice bran oil with methanol in the presence of a catalyst $(\mathrm{KOH})$. A two-stage process was used for the esterification of the crude rice bran oil [10]. The first stage (acid-catalyzed) of the process is to reduce the free fatty acids (FFA) content in cotton seed oil by esterification with methanol (99\% pure) and acid catalyst (sulfuric acid-98\% pure) in one hour time of reaction at $55^{\circ} \mathrm{C}$. In the second stage (alkali-catalyzed), the triglyceride portion of the cotton seed oil reacts with methanol and base catalyst (sodium hydroxide-99\% pure), in one hour time of reaction at $65{ }^{\circ} \mathrm{C}$, to form methyl ester and glycerol. To remove un-reacted methoxide present in raw methyl ester, it is purified by the process of water washing with air bubbling. The methyl ester (or biodiesel) produced from crude rice bran oil was known as rice bran oil biodiesel (BD). The properties of the Test fuels used in the experiment were presented in Table1.

\subsection{Engine with LHR Combustion Chamber}

Engine with LHR combustion chamber contained a two-part piston (Figue.1), the top crown made of low thermal conductivity material, superni was screwed to aluminum body of the piston, providing a $3 \mathrm{~mm}$ air gap in between the crown and the body of the piston.

The optimum thickness of air gap in the air gap piston was found to be $3 \mathrm{~mm}$ for improved performance of the engine with superni inserts with diesel as fuel [27]. A superni insert was screwed to the top portion of the liner in such a manner that an air gap of $3 \mathrm{~mm}$ was maintained between the insert and the liner body. At $500^{\circ} \mathrm{C}$ the thermal conductivity of superni and air are 20.92 and $0.057 \mathrm{~W} / \mathrm{m}-\mathrm{K}$. Partially stabilized zirconium (PSZ) of thickness 500 microns was coated by means of plasma coating technique. The combination of low thermal conductivity materials of air and superni provide sufficient insulation for heat flow thus resulting LHR combustion chamber. 

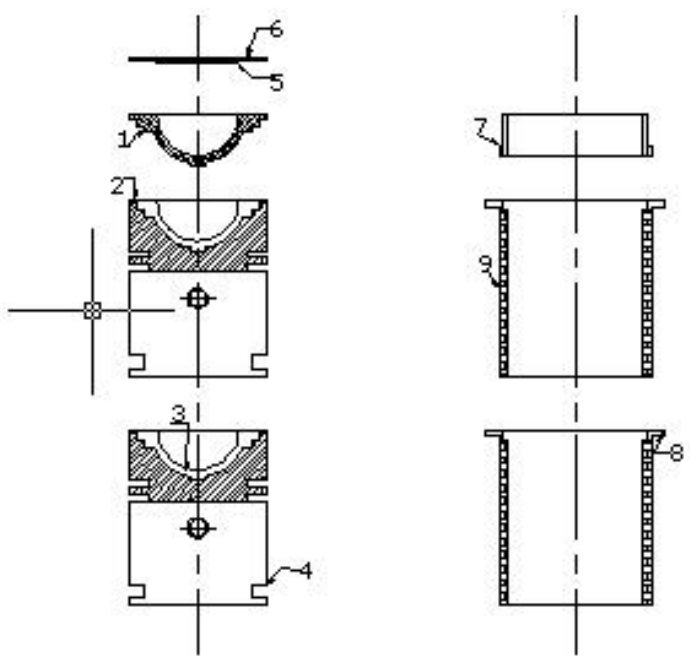

1.Superni piston crown with threads, 2. Superni gasket, 3. Air gap in piston, 4. Body of piston, 5. Ceramic coating on inside portion of cylinder head, 6. Cylinder head, 7.Superni insert with threads, 8.Air gap in liner, 9.Liner

Figure 1 Assembly details of air gap insulated piston, air gap insulated liner and ceramic coated cylinder head.

The physic-chemical properties of the biodiesel in comparison to ASTM standards are presented in Table-1.

Table 1 Properties of Test Fuels

\begin{tabular}{|c|c|c|c|c|}
\hline Fuel & $\begin{array}{c}\text { Specific } \\
\text { Gravity } \\
\text { at } \mathbf{4 0}^{\mathbf{C}} \mathbf{C}(\mathbf{c S t})\end{array}$ & $\begin{array}{c}\text { Cetane } \\
\text { Number }\end{array}$ & $\begin{array}{c}\text { Kinematic } \\
\text { Viscosity at } \mathbf{4 0}^{\mathbf{}} \mathbf{C} \\
\text { (cSt) }\end{array}$ & $\begin{array}{c}\text { Lower Calorific } \\
\text { value (kJ/kg) }\end{array}$ \\
\hline Diesel & 0.84 & 52 & 2.25 & 42000 \\
\hline Crude Vegetable oil (CRBO) & 0.90 & 45 & 4.5 & 39000 \\
\hline Biodiesel & 0.86 & 55 & 3.5 & 38500 \\
\hline ASTM Standard & ASTM D 4809 & ASTM D 4809 & ASTM D 445 & ASTM D 7314 \\
\hline
\end{tabular}

Schematic diagram of experimental setup used for the investigations on compression ignition diesel engine with rice bran biodiesel is shown in Figure.2. The test fuels used in the experimentation were neat diesel and biodiesel. The experimental engine was four-stroke, water cooled, single cylinder, $3.68 \mathrm{~kW}$ at the speed of $1500 \mathrm{rpm}$. The manufacturer's recommended injection timing and pressure were $27^{\circ} \mathrm{bTDC}$ and $190 \mathrm{bar}$. The bore of the engine was $80 \mathrm{~mm}$, while stroke was $110 \mathrm{~mm}$. The combustion chamber consisted of a direct injection type with no special arrangement for swirling motion of air. The engine was connected to an electric dynamometer for measuring its brake power. Burette method was used for finding fuel consumption of the engine. Air-consumption of the engine was measured by an air-box method (Air box was provided with an orifice flow meter and U-tube water manometer). The naturally aspirated engine was provided with water-cooling system in which outlet temperature of water was maintained at $80^{\circ} \mathrm{C}$ by adjusting the water flow rate. Engine oil was provided with a pressure feed system. No temperature control was incorporated, for measuring the lube oil temperature. The injector testing device was used to change the injector opening pressure from 190 bar to 270 bar (in steps of 40 bar). The maximum injector opening pressure was restricted to 270 bar due to practical difficulties involved. Exhaust gas temperature was measured with thermocouples made of iron and iron-constantan. Exhaust emissions of smoke and $\mathrm{NO}_{\mathrm{x}}$ were recorded by AVL (A company trade name) smoke meter and Netel Chromatograph (A company trade name) $\mathrm{NO}_{\mathrm{x}}$ analyzer respectively at full load operation of the engine. Various test fuels 
used in experimentation were neat diesel and biodiesel. Different operating conditions of the biodiesel were normal temperature and preheated temperature $\left(75^{\circ} \mathrm{C}\right)$. Different injector opening injector opening pressures attempted in this experimentation were $190 \mathrm{bar}, 230 \mathrm{bar}$ and 270 bar.

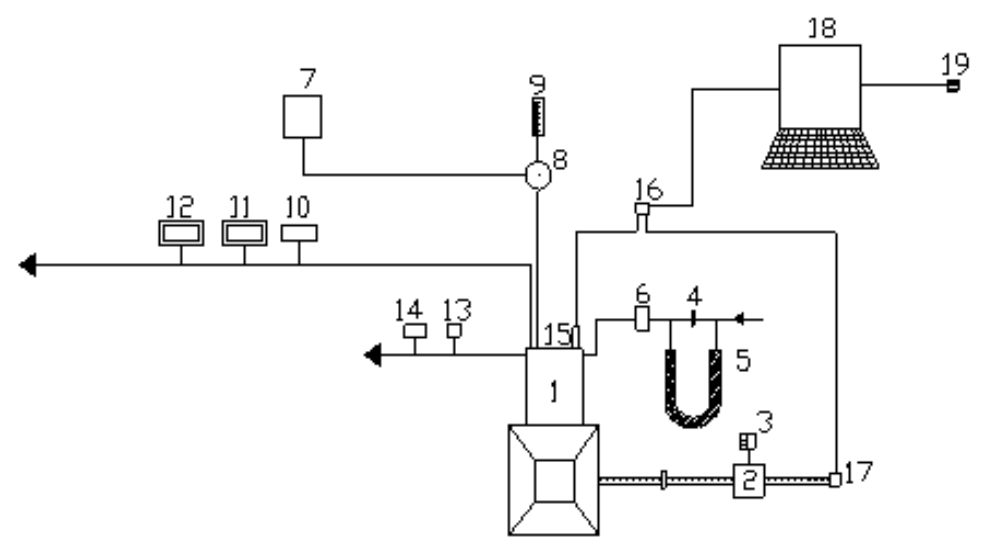

1.Engine, 2.Electical Dynamometer, 3.Load Box, 4.Orifice flow meter, 5.U-tube water manometer, 6.Air box, 7.Fuel tank, 8, Pre-heater, 9.Burette, 10. Exhaust gas temperature indicator, 11.AVL Smoke meter, 12.Netel Chromatograph NOx Analyzer, 13.Outlet jacket water temperature indicator, 14. Outlet-jacket water flow meter, 15.Piezo-electric pressure transducer, 16.Console, 17.TDC encoder, 18.Pentium Personal Computer and 19. Printer.

Figure 2 Experimental Set-up

\section{RESULTS AND DICUSSION}

\subsection{Exhaust Emissions}

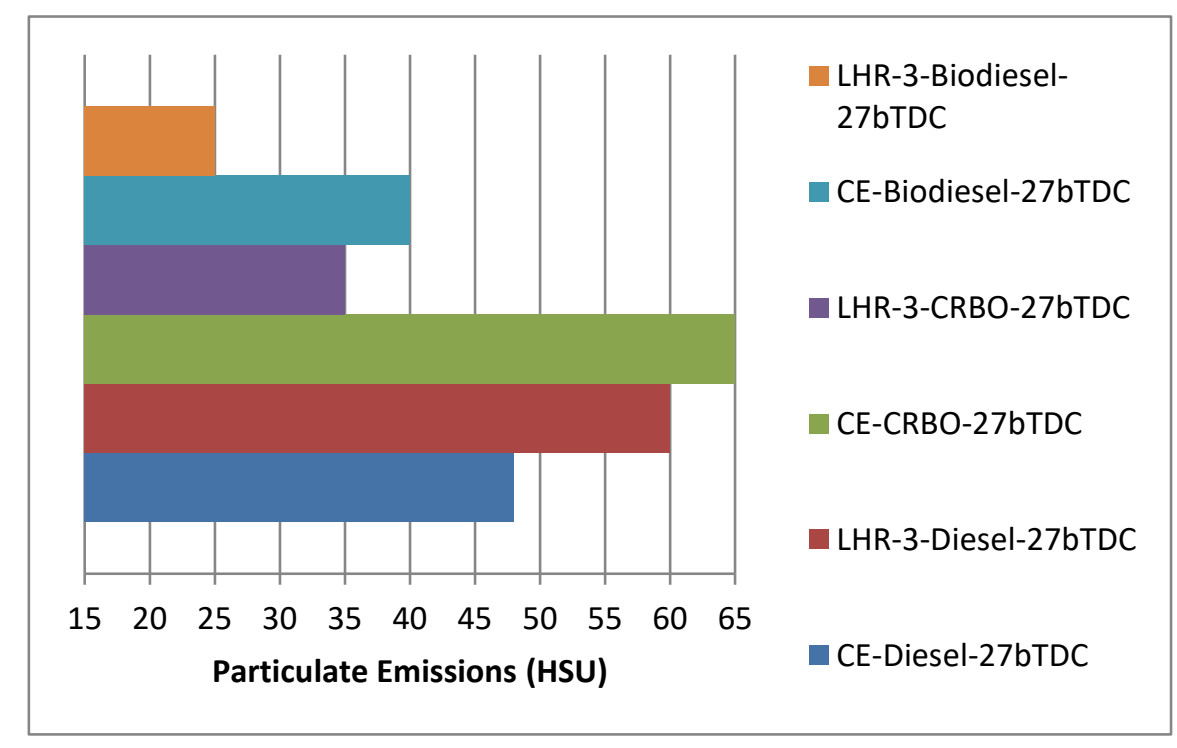

Figure 3 Bar charts showing the variation of particulate emissions in Hartridge smoke unit (HSU) at full load with test fuels.

Particulate emissions and $\mathrm{NO}_{\mathrm{x}}$ are the emissions from diesel engine cause health hazards like inhaling of these pollutants cause severe headache, tuberculosis, lung cancer, nausea, respiratory problems, skin cancer, hemorrhage, etc. [29-31]. The contaminated air containing carbon dioxide released from automobiles reaches ocean in the form of acid rain, there by polluting water. Hence control of these emissions is an immediate task and important. Fig.3. 
presents bar charts showing the variation of particulate emissions with both versions of the engine at recommended injection timing with test fuels at injection pressure of 190 bar Particulate emissions at full load decreased by $6 \%$ at recommended injection timing with biodiesel operation on CE in comparison with neat diesel (DF) operation. Presence of oxygen in fuel composition improved combustion, causing reduction of particulate emissions. LHR-3 engine reduced particulate emissions at full load by $59 \%$ at recommended injection timing with biodiesel operation in comparison with same version of the engine with neat diesel operation. LHR-3 engine reduced particulate emissions by $38 \%$ at recommended injection timing in comparison with $\mathrm{CE}$ with biodiesel operation, which showed that combustion improved with LHR-3 engine.

Crude vegetable oil operation on $\mathrm{CE}$ drastically increased particulate emissions in comparison with $\mathrm{CE}$ with neat diesel operation. Presence of fatty acids, higher value of $\mathrm{C} / \mathrm{H}$ $(\mathrm{C}=$ Number of carbon atoms, $\mathrm{H}=$ Number of hydrogen atoms in fuel composition), higher density, higher molecular weight and low volatility of crude vegetable oil increased particulate emissions in comparison with neat diesel operation on CE. LHR-3 engine with crude vegetable oil operation reduced particulate emissions by $46 \%$ at recommended injection timing and $40 \%$ at optimum injection timing in comparison with $\mathrm{CE}$ with crude vegetable oil operation, which showed that combustion improved with LHR-3 engine.

Particulate emissions at full load increased by $35 \%$ at recommended injection timing with crude vegetable oil operation on CE in comparison with neat diesel (DF) operation. LHR-3 engine reduced particulate emissions at full load by $42 \%$ at recommended injection timing with biodiesel operation in comparison with same version of the engine with neat diesel operation, which showed that LHR-3 engine was more suitable for crude vegetable oil operation. LHR3 engine with crude vegetable oil operation reduced particulate emissions by $46 \%$ at recommended injection timing in comparison with $\mathrm{CE}$ with crude vegetable oil operation, which showed that combustion improved with LHR-3 engine.

Table. 2 shows data of particulate emissions varied with injector opening pressure at different operating conditions of the crude vegetable oil and its biodiesel. Data from Table 2 shows a decrease in particulate emissions with different operating conditions of the vegetable oil and its biodiesel with both versions of the engine with increase of injector opening pressure. Improvement in spray characteristics might have reduced particulate emissions. Preheating of the crude vegetable oil and its biodiesel reduced particulate emissions, when compared with normal temperature of the test fuels. This was due to i) the reduction of density of the crude vegetable oil and its biodiesel, as density was directly related to particulate emissions, ii) the reduction of the diffusion combustion proportion with the preheated crude vegetable oil and its biodiesel iii) the reduction of the viscosity of the crude vegetable oil and its biodiesel, with which the fuel spray do not impinge on the combustion chamber walls of lower temperatures rather than it directed into the combustion chamber. Temperature and availability of oxygen are two favorable conditions to form $\mathrm{NO}_{\mathrm{x}}$ levels.

Figure.4 presents bar charts showing the variation of nitrogen oxide levels at full load with test fuels at recommended injection timing with both versions of the engine From Figure.4, it is noticed that $\mathrm{NO}_{\mathrm{x}}$ levels were drastically higher with biodiesel operation at all loads when compared with diesel operation with both versions of the engine. The rice bran biodiesel having long carbon chain $\left(\mathrm{C}_{20}-\mathrm{C}_{32}\right)$ recorded more NOx than that of fossil diesel having both medium $\left(\mathrm{C}_{8}-\mathrm{C}_{14}\right)$ as well as long chain $\left(\mathrm{C}_{16}-\mathrm{C}_{28}\right)$. The increase in NOx emission might be an inherent characteristic of biodiesel due to the presence of $54.9 \%$ of mono-unsaturated fatty acids(MUFA) and $18 \%$ of poly-unsaturated fatty acids (PUFA). That means, the long chain unsaturated fatty acids (MUFA and FUPA) such as oleic C18:1 and linoliec C18:2 fatty acids are mainly responsible for higher levels of NOx emission. Another reason for higher NOx levels 
is the oxygen $(10 \%)$ present in the methyl ester. The presence of oxygen in normal biodiesel leads to improvement in oxidation of the nitrogen available during combustion. This will raise the combustion bulk temperature responsible for thermal $\mathrm{NO}_{\mathrm{x}}$ formation. The production of higher NOx with biodiesel fueling is also attributable to an inadvertent advance of fuel injection timing due to higher bulk modulus of compressibility, with the in-line fuel injection system. Higher heat release rate of crude vegetable oil and its biodiesel in LHR3 engine might have increased nitrogen oxide levels in comparison with $\mathrm{CE}$ with test fuels. $\mathrm{NO}_{\mathrm{x}}$ levels decreased with $\mathrm{CE}$ with crude vegetable oil operation in comparison with $\mathrm{CE}$ with neat diesel operation. Lower heat release rate with deteriorated combustion might have produced lower nitrogen oxide levels with $\mathrm{CE}$ with crude vegetable oil operation in comparison with $\mathrm{CE}$ with neat diesel operation. From Figure.4, it is noticed that $\mathrm{NO}_{\mathrm{x}}$ levels decreased by $18 \%$ at recommended injection timing with $\mathrm{CE}$ with crude vegetable oil operation in comparison with neat diesel operation on CE. LHR-3 engine showed comparable nitrogen oxide levels at full load at recommended injection timing and $14 \%$ at optimum injection timing with crude vegetable oil operation in comparison with same version of the engine with neat diesel operation, which showed that LHR-3 engine produced higher heat release rates and more suitable for crude vegetable oil operation.. From Fig.4, it is noticed that $\mathrm{NO}_{\mathrm{x}}$ levels increased by $12 \%$ at recommended injection timing and $5 \%$ at optimum injection timing with $\mathrm{CE}$ with biodiesel operation in comparison with neat diesel operation. LHR-3 engine increased nitrogen oxide levels by $4 \%$ at full load at recommended injection timing with biodiesel operation in comparison with same version of the engine with neat diesel operation, which showed that LHR-3 engine produced higher heat release rates and more suitable for biodiesel.LHR-3 engine increased $\mathrm{NO}_{\mathrm{x}}$ levels by $42 \%$ at recommended injection timing in comparison with $\mathrm{CE}$ with biodiesel operation

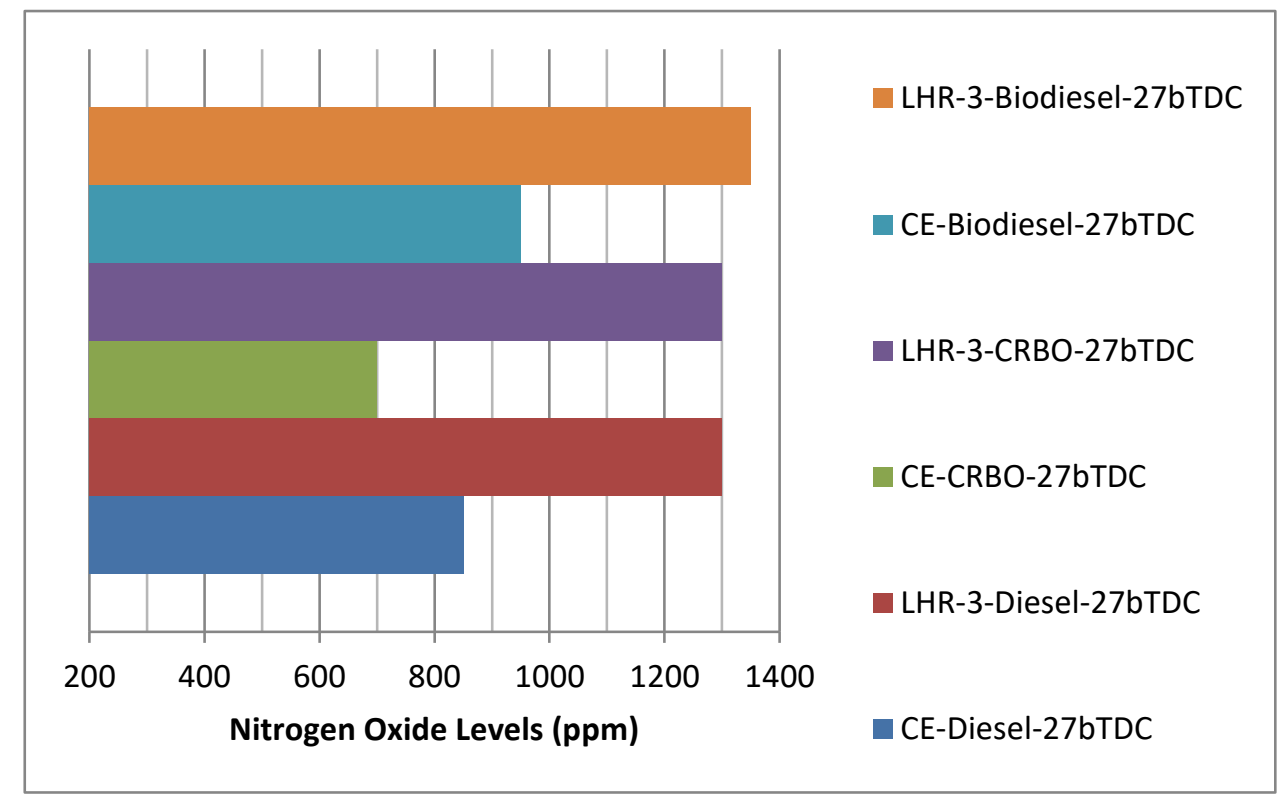

Figure 4 Bar charts showing the variation of nitrogen oxide levels $\left(\mathrm{NO}_{\mathrm{x}}\right)$ at full load operation with test fuels

Table. 2 shows data of nitrogen oxide levels with varied injector opening pressure at different operating conditions with test fuels. From the Table 2, it is noted that NOx levels increased with increase of injector opening pressure with different operating conditions of crude vegetable oil and its biodiesel. $\mathrm{NO}_{x}$ slightly increased with test fuels as injector opening pressure increased. This was because of improved combustion causes higher peak brake thermal efficiency due to higher combustion chamber pressure and temperature, which leads to higher 
$\mathrm{NO}_{x}$ formation. This is an evident proof of enhanced spray characteristics, thus improving fuel air mixture preparation and evaporation process. LHR-3 engine with vegetable oil operation increased $\mathrm{NO}_{\mathrm{x}}$ levels by $86 \%$ at recommended injection timing in comparison with $\mathrm{CE}$ with crude vegetable oil operation. $\mathrm{NO}_{\mathrm{x}}$ levels increased with test fuels with $\mathrm{CE}$, while marginal reduction of $\mathrm{NO}_{x}$ levels with LHR-3 engine was observed with advanced injection timing Residence time and availability of oxygen had increased, when the injection timing was advanced with test fuels, which caused higher $\mathrm{NO}_{\mathrm{x}}$ levels in $\mathrm{CE}$, while improved combustion with improved air fuel ratios were responsible for reduction of $\mathrm{NO}_{\mathrm{x}}$ levels in LHR-3 engine with biodiesel operation.

Tabe 2 Data of exhaust emissions at full load operation

\begin{tabular}{|c|c|c|c|c|c|c|c|c|c|c|c|c|c|c|}
\hline \multirow{4}{*}{$\begin{array}{l}\text { Injection } \\
\text { Timing } \\
\text { ('bTDC) }\end{array}$} & \multirow{4}{*}{$\begin{array}{l}\text { Test } \\
\text { Fuel }\end{array}$} & \multirow{4}{*}{$\begin{array}{l}\text { Engine } \\
\text { version }\end{array}$} & \multicolumn{6}{|c|}{$\begin{array}{c}\text { Particulate emissions } \\
\text { (Hartridge Smoke Unit) }\end{array}$} & \multicolumn{6}{|c|}{ NO ${ }_{x}$ Levels (ppm) } \\
\hline & & & \multicolumn{6}{|c|}{ Injector Opening Pressure (Bar) } & \multicolumn{6}{|c|}{ Injector Opening Pressure (Bar) } \\
\hline & & & \multicolumn{2}{|c|}{190} & \multicolumn{2}{|c|}{230} & \multicolumn{2}{|c|}{270} & \multicolumn{2}{|c|}{190} & \multicolumn{2}{|c|}{230} & \multicolumn{2}{|c|}{270} \\
\hline & & & NT & PT & NT & PT & NT & PT & NT & PT & NT & PT & NT & PT \\
\hline \multirow{6}{*}{27} & DF & $\mathrm{CE}$ & 48 & -- & 38 & -- & 34 & -- & 850 & $\begin{array}{ll}--- \\
-\end{array}$ & 900 & ---- & 950 & --- \\
\hline & $\mathrm{CRBO}$ & $\mathrm{CE}$ & 65 & 60 & 60 & 55 & 55 & 50 & 700 & 650 & 750 & 700 & 800 & 750 \\
\hline & Biodiesel & $\mathrm{CE}$ & 40 & 35 & 35 & 30 & 30 & 25 & 950 & 900 & 1000 & 950 & 1050 & 1000 \\
\hline & DF & LHR-3 & 60 & -- & 55 & -- & 50 & -- & 1300 & -- & 1250 & -- & 1200 & -- \\
\hline & CRBO & LHR-3 & 35 & 30 & 30 & 25 & 25 & 20 & 1300 & 1250 & 1250 & 1200 & 1200 & 1150 \\
\hline & Biodiesel & LHR-3 & 25 & 20 & 20 & 15 & 20 & 15 & 1350 & 1300 & 1300 & 1250 & 1250 & 1200 \\
\hline
\end{tabular}

$\mathrm{NO}_{\mathrm{x}}$ levels decreased with preheating of the crude vegetable oil and biodiesel as noticed from the Table. 2 The fuel spray properties may be altered due to differences in viscosity and surface tension. The spray properties affected may include droplet size, droplet momentum, degree of mixing, penetration, and evaporation. The change in any of these properties may lead to different relative duration of premixed and diffusive combustion regimes. Since the two burning processes (premixed and diffused) have different emission formation characteristics, the change in spray properties due to preheating of the crude vegetable oil and its biodiesel are lead to reduction in $\mathrm{NO}_{\mathrm{x}}$ formation. As fuel temperature increased, there was an improvement in the ignition quality, which will cause shortening of ignition delay.

\section{CONCLUSIONS}

Particulate emissions at full load decreased by $39 \%$ at recommended injection timing with biodiesel operation on CE in comparison with same version of the engine with crude vegetable oil operation. LHR-3 engine reduced particulate emissions at full load by $29 \%$ at recommended injection timing with biodiesel operation in comparison with same version of the engine with crude vegetable oil operation.

$\mathrm{NO}_{\mathrm{x}}$ levels increased by $36 \%$ at recommended injection timing with $\mathrm{CE}$ with biodiesel operation in comparison same version of the engine with crude vegetable oil operation. LHR3 engine increased nitrogen oxide at full load by $4 \%$ at recommended injection timing with biodiesel operation in comparison with same version of the engine with crude vegetable oil operation.

With increase of injector opening pressure, particulate emissions decreased, while NOx levels increased in CE, while in LHR engine, particulate emissions and NOx levels decreased with test fuels of crude vegetable oil and its biodiesel.

With preheating, decrease of particulate emissions and $\mathrm{NO}_{\mathrm{x}}$ levels were observed with crude vegetable oil and its biodiesel with both versions of the engine. 


\section{FUTURE SCOPE OF STUDIES}

In order to reduce nitrogen oxide levels from LHR engine with biodiesel, selective catalytic reduction technique can be employed. [32]

\section{ACKNOWLEDGMENTS}

Authors thank authorities of Chaitanya Bharathi Institute of Technology, Hyderabad for providing facilities for carrying out this research work. Financial assistance provided by All India Council for Technical Education (AICTE), New Delhi, was greatly acknowledged.

\section{REFERNCES}

[1] Matthias Lamping, Thomas Körfer, Thorsten Schnorbus, Stefan Pischinger, Yunji Chen. Tomorrows Diesel Fuel Diversity - Challenges and Solutions, SAE 2008-01 1731.2008.

[2] Agarwal, A.K. Bio-fuels (alcohols and biodiesel) applications as fuels for internal combustion engines, International Journal Energy Combustion Science, 33, 2007, pp. 233-271

[3] Devan, P.K. and Mahalakshmi, N.V. Performance, emission and combustion characteristics of poon oil and its blends in a DI diesel engine, Fuel, 88,2009, pp. 861-870.

[4] Agarwal, A.K. and Dhar A.Comparative performance, emission and combustion characteristics of rice-bran oil and its biodiesel in a transportation diesel engine. Journal of Engineering for Gas Turbines and Power, Transactions of ASME,132, 2010, pp. 064503.1 -064503.4

[5] Misra, R.D., Murthy, M.S. Straight vegetable oils usage in a compression ignition engine A review, Renewable and Sustainable Energy Reviews, 14, 2010, pp. 3005-3013.

[6] Venkateswara Rao, N., Murali Krishna, M.V.S. and Murthy,P.V.K. Comparative studies on exhaust emissions and combustion characteristics of tobacco seed oil in crude form and biodiesel form in direct injection diesel engine, International Journal of Mechanical and Production Engineering Research and Development, 3(4), 2013, pp. 125-138.

[7] Avinash Kumar Agarwal and Atul Dhar. Experimental investigations of performance, emission and combustion characteristics of Karanja oil blends fuelled DICI engine, Renewable Energy, 52,2013, pp.283-291.

[8] McCarthy, P., Rasul, M.G., Moazzem, S. Analysis and comparison of performance and emissions of an internal combustion engine fuelled with petroleum diesel and different biodiesels. Fuel, 90, 2011, pp. 2147-2157

[9] Xue, J., Grift, T.E., Hansen, A.C. Effect of biodiesel on engine performances and emissions. Renewable and Sustainable Energy Reviews,15, 2011, pp.1098-1116.

[10] Anirudh Gautam and Avinash Kumar Agarwal. Experimental investigations of comparative performance, emission and combustion characteristics of a cottonseed biodiesel fueled fourstroke locomotive diesel engine, Int J Engine Res, 14, 2013, pp 354-360

[11] Durga Prasada Rao, N., Murali Krishna, M.V.S., Anjeneya Prasad, B. and Murthy, P.V.K. Effect of injector opening pressure and injection timing on exhaust emissions and combustion characteristics of Jatropha oil in crude form and biodiesel form in direct injection diesel engine. IOSR Journal of Engineering, 4(2), 2014, pp 9-19.

[12] Bari, S., Lim, T.H., Yu, C.W. Effect of preheating of crude palm oil on injection system, performance and emission of a diesel engine, Renewable Energy, 27(3), 2002, pp. 339-351. 
[13] Nwafor, O.M.L. The effect of elevated fuel inlet temperature on the performance of diesel engine running on a neat vegetable oil at constant speed conditions, Renewable energy, 28, 2003,pp. 171-180.

[14] Senthil Kumar, M., Kerihuel, A., Bellettre, J. and Tazerout, M. Experimental investigations on the use of preheated animal fat as fuel in a compression ignition engine, Renewable Energy, 30,2005, pp. 2314-2323.

[15] Agarwal, D., Agarwal, A.K. Performance and emissions characteristics of jatropha oil (preheated and blends) in a direct injection compression ignition engine, Int. J. Applied Thermal Engineering, 27, 2007, pp. 2314-23.

[16] Heywood, J.B. (Fundamentals of Internal Combustion Engines. Tata McGraw Hills, New York, 1988.

[17] Celikten, I. An experimental investigation of the effect of the injection pressure on the engine performance and exhaust emission in indirect injection diesel engines, Applied Thermal Engineering, 23, 2003, pp. 2051-2060.

[18] Cingur, Y. and Altiparmak, D. Effect of cetane number and injection pressure on a DI diesel engine performance and emissions, Energy Conversion and Management, 44, 2003, pp. 389397.

[19] Hountalas, D.T., Kouremenos, D.A., Binder, K.B., Schwarz, V. and Mavropoulos, G.C. Effect of injection pressure on the performance and exhaust emissions of a heavy duty DI diesel engine, SAE Technical Paper No. 2003-01-0340. Warrendale, PA.2003.

[20] Venkanna, B.K. and Venkataramana, R.C. Influence of fuel injection rate on the performance, emission and combustion characteristics of DI diesel engine running on calophyllum inophyllum linn oil (honne oil)/diesel fuel blend, SAE Technical Paper No. 2010-01-1961, 2010.

[21] Ratna Reddy, T., Murali Krishna, M.V.S., Kesava Reddy, Ch, et al. (2012), Performance evaluation of a low heat rejection diesel engine with mohr oil based biodiesel. British J Appl Sci \& Technol, 2(2), pp. 179-198.

[22] Venkateswara Rao, N., , Murali Krishna, M.V.S. and Murthy, P.V.K. Effect of injector opening pressure and injection timing on performance parameters of high grade low heat rejection diesel engine with tobacco seed oil based biodiesel, Int J Current Eng \& Tech, 3(4), 2913, pp.14011411.

[23] Subba Rao, B., Ramjee, E., Murthy, P.V.K., et al. Studies on exhaust emissions and combustion characteristics of tobacco seed oil in crude form and biodiesel from a high grade low heat rejection diesel engine. Int J Industrial Eng Technol, 3(1, 2013, pp. 27-36.

[24] Chowdary, R.P., Murali Krishna, M.V.S., Reddy, T.K.K. and Murthy,P.V.K. Performance evaluation of a high grade low heat rejection diesel engine with waste fried vegetable oil. International Journal of Engg \& Technology, 2(3),2012, pp. 440-450

[25] Kesava Reddy, Ch., Murali Krishna, M.V.S., Murthy, P.V.K. and Ratna Reddy, T. Performance evaluation of a high grade low heat rejection diesel engine with crude pongamia oil. International Journal of Engineering Research and Applications, 2(5), 2912, pp. 1505-1516. 
[26] Janardhan, N., Murali Krishna, M.V.S., Ushasri, P. and Murthy, P.V.K. Performance of evaluation of a low heat rejection diesel engine with jatropha oil, International Journal of Engineering Research in Africa. 11, 2913, pp. 27-44.

[27] Rama Mohan, K., Vara Prasad, C.M., Murali Krishna, M.V.S. Performance of a low heat rejection diesel engine with air gap insulated piston, ASME Journal of Engineering for Gas Turbines and Power, 121(3),1999, pp. 530-540.

[28] Murali Krishna, M.V.S., Janardhan, N., Kesava Reddy, Ch. and Krishna Murthy, P.V. Experimental investigations on DI diesel engine with different combustion chambers, British Journal of Applied Science \& Technology, 6(3), 2914, pp.239-260.

[29] Fulekar, M. H. Chemical pollution - a threat to human life, Indian Journal of Environmental Technology, 1, 1999, pp. 353-359.

[30] Khopkar, S.M. Environmental Pollution Analysis, [New Age International (P) Ltd, Publishers, New Delhi], 2004, pp. 180-190.

[31] Sharma, B.K. Engineering Chemistry, [Pragathi Prakashan (P) Ltd, Meerut], 2005, pp. 150-160.

[32] Janardhan, N., Ushasri,P., Murali Krishna,M.V.S., and Murthy, P.V.K. Performance of biodiesel in low heat rejection diesel engine with catalytic converter. International Journal of Engineering and Advanced Technology, 2(2), 2012, pp.97-109. 